\title{
Sr36- and Sr5-Mediated Resistance Response to Puccinia graminis f. sp. tritici Is Associated with Callose Deposition in Wheat Guard Cells
}

\author{
X. Wang, B. D. McCallum, T. Fetch, G. Bakkeren, and B. J. Saville
}

First, second, and third authors: Cereal Research Centre, Agriculture and Agri-Food Canada, 101 Route 100, Morden, MB, R6M 1Y5, Canada; fourth author: Pacific Agri-Food Research Centre, Agriculture and Agri Food Canada, Summerland, BC, VOH 1ZO, Canada; and fifth author: Forensic Science Program, and Environmental and Life Sciences Graduate Program Trent University, Peterborough, ON, K9J 7B8, Canada. Accepted for publication 17 February 2015.

\begin{abstract}
Wang, X., McCallum, B. D., Fetch, T., Bakkeren, G., and Saville, B. J. 2015. Sr36- and Sr5-mediated resistance response to Puccinia graminis f. sp. tritici is associated with callose deposition in wheat guard cells. Phytopathology 105:728-737.

Race-specific resistance of wheat to Puccinia graminis f. sp. tritici is primarily posthaustorial and often involves the induction of a hypersensitive response (HR). The aim of this study was to investigate host defense responses induced in interactions between $P$. graminis $\mathrm{f}$. sp. tritici races and wheat lines carrying different race-specific stem rust resistance $(\mathrm{Sr})$ genes. In incompatible interactions between wheat lines carrying Sr36 in three genetic backgrounds (LMPG, Prelude, or W2691) and avirulent $P$. graminis f. sp. tritici races MCCFC or RCCDM, callose accumulated within $24 \mathrm{~h}$ in wheat guard cells contacted by a $P$. graminis $\mathrm{f}$. sp. tritici appressorium, and $P$. graminis f. sp. tritici ingress was inhibited following appressorium formation. Accordingly, the expression of tran-

Furthermore, the inhibition of callose synthesis through the infiltration of 2-deoxy-D-glucose (DDG) increased the ability of $P$. graminis f. sp. tritici race MCCFC to infect LMPG-Sr36. A similar induction of callose deposition in wheat guard cells was also observed within $24 \mathrm{~h}$ after inoculation (hai) with avirulent $P$. graminis $\mathrm{f}$. sp. tritici race HKCJC on LMPG-Sr 5 plants. In contrast, this defense response was not induced in incompatible interactions involving $\operatorname{Sr} 6, \operatorname{Sr} 24$, or $\operatorname{Sr} 30$. Instead, the induction of an HR and cellular lignification were noted. The manifestation of the HR and cellular lignification was induced earlier (24 hai) and was more extensive in the resistance response mediated by $\operatorname{Sr} 6$ compared with those mediated by $\operatorname{Sr} 24$ or $\mathrm{Sr} 30$. These results indicate that the resistance mediated by $\mathrm{Sr} 36$ is similar to that mediated by $\operatorname{Sr} 5$ but different from those triggered by $\operatorname{Sr} 6, \operatorname{Sr} 24$, or $\mathrm{Sr} 30$. Resistance responses mediated by $\mathrm{Sr} 5$ and $\mathrm{Sr} 36$ are prehaustorial, and are a result of very rapid recognition of molecules derived from avirulent isolates of $P$. graminis f. sp. tritici, in contrast to the responses triggered in lines with $\operatorname{Sr} 6, \operatorname{Sr} 24$, and $\operatorname{Sr} 30$.
\end{abstract} scripts encoding a callose synthase increased in the incompatible interaction between LMPG-Sr36 and avirulent $P$. graminis f. sp. tritici race MCCFC.

Wheat stem rust, caused by Puccinia graminis f. sp. tritici, has historically been the most devastating disease in wheat (Triticum aestivum L.)-growing regions worldwide. It infects wheat stems and leaf sheaths, which interrupts host nutrient flow to the developing head and results in shriveled grain, lodging, and loss of grain (Roelfs et al. 1992). Stem rust has been successfully controlled for over 50 years by the deployment of effective resistance genes and the eradication of alternate sexual host barberry (Berberis vulgaris), which reduces pathogen diversity and survivability (Leonard and Szabo 2005). Nevertheless, the recent discovery of $P$. graminis $\mathrm{f}$. $\mathrm{sp}$. tritici race TTKSK (Ug99) and its derivatives in Africa, which carry virulence toward several stem rust resistance $(\mathrm{Sr})$ genes commonly utilized in wheat cultivars, poses a severe threat to wheat production worldwide (Njau et al. 2010; Pretorius et al. 2000; Singh et al. 2011). The infection process for P. graminis f. sp. tritici on wheat leaves starts with the deposition of a urediniospore on the surface of the leaf. The urediniospore germinates to form a germ tube which grows perpendicular to the leaf veins until it encounters a stomate. Once a stomate is recognized by the topology of the guard cells, a specialized infection structure called an appressorium forms over the stomate. From the appressorium, penetration takes place through stomatal openings by the formation of a penetration peg which grows between the guard cells, whereupon a vesicle is formed in the substomatal cavity, from which a primary infection hypha emerges. The initiation of the intercellular biotrophic infection

Corresponding author: X. Wang; E-mail address: Xiben.Wang@agr.gc.ca
Additional keywords: wheat stem rust.

process involves the formation of a haustorial mother cell which penetrates the host cell wall to form an intracellular haustorium, as well as secondary infection hyphae for intercellular spread (Leonard and Szabo 2005).

To date, $58 \mathrm{Sr}$ genes have been officially designated, and the majority of these genes are race specific (Leonard and Szabo 2005; McIntosh et al. 1995). Most $\mathrm{Sr}$ genes are introduced from either T. aestivum or its wild relatives. For instance, $\operatorname{Sr} 5$ was introduced from the common wheat and Sr6 and Sr30 originated from T. aestivum, whereas $\mathrm{Sr} 24$ and $\mathrm{Sr} 36$ were introgressed from Thinopyrum ponticum and T. timopheevii, respectively (McIntosh et al. 1995). The seedling resistance mediated by $\mathrm{Sr}$ genes can range from immune to intermediate, depending on the interaction with a particular $P$. graminis $\mathrm{f}$. sp. tritici race (carrying a cognate avirulence $[a v r]$ gene) (Leonard and Szabo 2005). In the immune infection type (IT 0), the growth of $P$. graminis f. sp. tritic $i$ is stopped at a very early stage of infection, whereas colonies of $P$. graminis $\mathrm{f}$. sp. tritici in a moderately resistant IT ( 1 to 2 ) continue to grow, albeit at a reduced rate compared with the fully susceptible ITs (3 to 4), and usually form smaller pustules producing fewer urediniospores. In the immune resistance response mediated by $S r 5, P$. graminis f. sp. tritici infection was stopped when only one or two $P$. graminis f. sp. tritici haustorial mother cells were produced per colony, and there was no further fungal growth beyond $24 \mathrm{~h}$ after the initial penetration through stomata (Rohringer and Heitefuss 1984). Similarly, haustoria mother cells were rarely produced in a wheat differential line carrying Sr36 inoculated with $P$. graminis f. sp. tritici races 151-QSH and 56-MBC, which produced IT 0 to IT; (Rowell 1981). In comparison, wheat cultivars carrying Sr6, Sr8a, or $S r 22$ developed small pustules when inoculated with avirulent 
P. graminis f. sp. tritici races (Rohringer et al. 1979), and colonies of avirulent $P$. graminis f. sp. tritici races in plants carrying $\mathrm{Sr} 9 b$ continued to grow until leaves began to senesce (Bushnell 1970). The difference in the effectiveness of resistance mediated by different $S r$ genes might be caused by the timing of induction of host defense response or gene dosage effects. It is also possible that this difference is due to the function of resistance genes and the types of host defense responses regulated by these resistance genes.

The resistance response mediated by race-specific $\mathrm{Sr}$ genes usually involves the elicitation of a hypersensitive response (HR) and cellular lignification through the recognition of postulated P. graminis f. sp. tritici avr gene products by its host (Leonard and Szabo 2005; Rohringer et al. 1979). HR could affect the nutrient status of host cells and produce molecules that are harmful to pathogens (Leonard and Szabo 2005). Additionally, a previous study showed that treatments with cellular lignification inhibitors decreased the frequency of lignified necrotic host cells in wheat line Prelude carrying $S r 5$ when subsequently inoculated with an avirulent $P$. graminis f. sp. tritici race 32, resulting in an increase of fungal growth. This suggested a causal relationship between cellular lignification and wheat resistance to $P$. graminis f. sp. tritici (Moerschbacher et al. 1990).

Defense responses mediated by race-specific $\mathrm{Sr}$ genes have been reported to be primarily posthaustorial (Bolton et al. 2008; Leonard and Szabo 2005; Rohringer et al. 1979). In this type of interaction, the growth of the fungus is arrested after the formation of haustoria. In several histological studies of incompatible interactions between a rust fungus and its host, visible host defense responses, mainly an HR, were not induced until rust fungus penetrated host cells and formed haustoria (Rohringer et al. 1979; Rohringer and Heitefuss 1984). Because of this timing and the fact that race-specific resistance relies on the recognition of pathogen effectors by host resistance (R) proteins as Avr factors, it has been suggested that the rust haustorium secretes effectors and that the haustorium-host cell interface plays an important role in the interaction between rust fungus and its host. This hypothesis is supported by the study of Catanzariti et al. (2006), in which predicted secreted proteins expressed in haustoria of the flax rust fungus, Melampsora lini, were highly enriched for Avr elicitors. However, more recently, it was shown that the host defense response mediated by Rpgl in barley was triggered at a very early, prehaustorial stage of the infection process when $P$. graminis $\mathrm{f}$. sp. tritici urediniospores just landed on the leaf surface (Nirmala et al. 2011). Similarly, a rapid accumulation of callose around the infection site was observed in Thatcher- $\operatorname{Lr} 9$ wheat when inoculated with avirulent $P$. triticina race BBBD. In this interaction, most $P$. triticina colonies failed to produce any haustoria (Wang et al. 2012). These various reports suggest that the host resistance responses to specific rust races may include callose deposition and cellular lignification as well as an HR. These defense responses can be induced both before and after the formation of haustoria.

In Arabidopsis, the callose synthase GSL5/PMR4 is induced in response to pathogen-associated molecular patterns (PAMPs) and fungal pathogens (Jacobs et al. 2003; Nishimura et al. 2003). In addition, callose deposition was shown to depend on PAMP-induced glucosinolates in Arabidopsis (Clay et al. 2009). Previously, we demonstrated that the deposition of callose was induced in the racespecific resistance response mediated by wheat leaf rust resistance gene $\operatorname{Lr} 9$, which confers an immune reaction to $P$. triticina race BBBD (Wang et al. 2012). Therefore, we wondered whether the production of callose is induced during the interaction between wheat and $P$. graminis f. sp. tritici and, if so, whether its deposition can also contribute to stem rust resistance.

In this study, we hypothesized that HR, cellular lignification, and callose deposition may contribute to the race-specific resistance of wheat against stem rust fungi. To investigate the involvement of these resistance responses mediated by $\mathrm{Sr}$ genes, we compared $\mathrm{Sr}$ genes representing three levels of resistance triggered by the interactions with specific races of $P$. graminis f. sp. tritici. Sr5 and Sr36 are capable of conferring immunity (IT 0), Sr6 is rated as highly resistant (IT $0 ; 1$ ), and $S r 24$ or $S r 30$ are only moderately resistant (IT 2). All of these $\mathrm{Sr}$ genes are currently utilized in various stem rust resistance breeding programs and have been extensively studied. In addition, the availability of these $S r$ genes in wheat differential lines allows us to compare the sequence of defense responses mediated by these $\mathrm{Sr}$ genes and minimize effects caused by host genetic backgrounds. We compared cellular responses (callose deposition, HR-based necrotic cell death, lignification, and the expression of two genes involved in these processes, callose synthase and phenylalanine ammonia lyase) that occur when wheat lines carrying $S r 5, S r 6, S r 24, S r 30$, or $S r 36$ interact with $P$. graminis f. sp. tritici races that produce various degrees of compatible or incompatible reactions upon infection. In these interactions, events were monitored through visual observation, fluorescent microscopy, and reverse-transcription quantitative polymerase chain reaction (RT-qPCR) analysis to compare and contrast the resistance mechanisms involved with each of these resistance genes.

\section{MATERIALS AND METHODS}

Plant and fungal materials. Wheat near-isogenic lines carrying resistance genes $\mathrm{Sr} 5, \mathrm{Sr} 6, \mathrm{Sr} 24, \mathrm{Sr} 30$, or $\mathrm{Sr} 36$ in a Little club/ Marquis/Prelude/Gabo (LMPG) background were obtained from Dr. Knott, University of Saskatchewan (Knott 1990). Additional wheat lines carrying Sr36 in Prelude and W2691 backgrounds were obtained from the Cereal Research Centre, Morden, MB, Canada. P. graminis f. sp. tritici isolates with designations 1541 (virulence phenotype MCCFC), 1563 (virulence phenotype RCCDM), 1345 (virulence phenotype RHTSC), 1347 (virulence phenotype QTHJF), and 1176 (virulence phenotype HKCJC) were obtained from isolates kept at the Cereal Research Centre, Morden. Isolates were increased and their virulence phenotypes were verified using 20 standard differential lines and the international letter code nomenclature (Jin et al. 2008).

Plant growth and inoculation conditions. Stem rust urediniospores were suspended in Bayol oil and adjusted to a concentration of $5 \times 10^{6}$ urediniospores $/ \mathrm{ml}$. Seven-day-old wheat plants at the two-leaf stage were inoculated with $P$. graminis f. sp. tritici by spraying with $700 \mu \mathrm{l}$ of urediniospore-oil suspension per flat, holding 100 seedlings. After the inoculation, wheat plants were incubated in a moisture chamber at $100 \%$ relative humidity overnight at $18^{\circ} \mathrm{C}$ followed by an incubation period of $3 \mathrm{~h}$ with illumination. Then they were transferred to a growth chamber set to cycles of $18 \mathrm{~h}$ with illumination followed by $6 \mathrm{~h}$ of darkness at $18^{\circ} \mathrm{C}$ (Fetch et al. 2010). Inoculated plants were rated for IT at 10 days after inoculation (DAI) using a 0-to-4 scale (Stakman et al. 1962).

Microscopy techniques. To visualize infection structures of $P$. graminis f. sp. tritici, wheat leaves were fixed in ethanol/ tricholoromethane $(3: 1, \mathrm{vol} / \mathrm{vol})$ solution containing $0.15 \%$ trichloroacetic acid for $24 \mathrm{~h}$ and subsequently washed once with $50 \%$ ethanol (vol/vol). Fixed-leaf samples were incubated at $90^{\circ} \mathrm{C}$ for $30 \mathrm{~min}$ in $0.5 \mathrm{M} \mathrm{NaOH}$, then rinsed once with water, followed by incubation in $0.1 \mathrm{M}$ Tris- $\mathrm{HCl}(\mathrm{pH} 5.8)$ for $30 \mathrm{~min}$. Subsequently, leaves were stained with $0.1 \%$ Uvitex 2 B (Analychem Corp. Ltd., Mississauga, Ontario, Canada) for 5 min followed by five washes with distilled water. Specimens were mounted in $50 \%$ (vol/vol) glycerol and observed under a Leica fluorescent microscope. The number of haustorial mother cells produced by $P$. graminis f. sp. tritici was counted visually under a microscope.

Wheat cells undergoing hypersensitive cell death were identified using lactophenol-trypan blue staining, as described by Koch and Slusarenko (1990). Stained leaves were mounted on a microscope slide in 50\% glycerol and examined using a Leica light microscope. Staining of lignin was conducted using phloroglucinol-HCl, as described by Vance and Sherwood (1976), on leaves prepared for Uvitex2B staining, as described above. Briefly, leaves were soaked in phloroglucinol (4\% [wt/vol] in $20 \%$ ethanol) for $30 \mathrm{~min}$ and then mounted on microscope slides. One drop of $6 \mathrm{~N} \mathrm{HCl}$ was added onto 
the sample, and the slide was heated on a hot plate until the red lignin coloration appeared. The accumulation of callose in infected leaves was revealed by aniline blue staining, as described by Adam and Somerville (1996). Leaf samples were fixed in ethanol/tricholoromethane (3:1, vol/vol) solution containing $0.15 \%$ trichloroacetic acid for $24 \mathrm{~h}$. Leaves were then washed once with $50 \%$ ethanol ( $\mathrm{vol} / \mathrm{vol}$ ) followed by a rinse with distilled water. Subsequently, leaf samples were stained with $0.01 \%$ aniline blue in 0.1 M Tris (pH 9.0) overnight. Samples were mounted in $50 \%$ glycerol and examined by epifluorescent illumination.

For leaf samples stained with Uvitex2B and aniline blue, fluorescence was examined using a Leica DMRB microscope equipped with a fiber optic light source and a 4',6-diamidino-2-phenylindole filter cube (excitation range $=400 \mathrm{~nm}$ ). Images were recorded with a Leica DFC360FX camera. The autofluorescence emitted from necrotic cells was observed with a Leica Fred filter cube (excitation range $=550 \mathrm{~nm}$ ). Images were then overlaid using Leica image overlay software (version 3.6). Histopathological analysis was conducted on more than 100 leaves collected from multiple inoculations for each treatment, and only representative pictures were presented. The analysis of infection sites showing various defense responses was performed on 10 leaf segments ( $2 \mathrm{~cm}$ in length) per flat, and three flats were included for each interaction. The experiment was repeated twice.

RT-qPCR analysis of transcripts related to genes involved in callose synthesis, HR, and cellular lignification. Total RNA was extracted from infected leaves using the RNAeasy Plant Mini Kit (Qiagen, Mississauga, Ontario, Canada) and treated with RNase-free DNase (Qiagen) following the manufacturer's instructions. cDNA synthesis was conducted using the iScript reverse-transcription kit for RT-qPCR (BioRad, Mississauga, Ontario, Canada), following the manufacturer's recommended method, and $1 \mu \mathrm{g}$ of total RNA. The cDNA products were diluted 1:20 using nuclease-free water prior to use. All qPCR assays were performed on a CFX96 Real-Time PCR system (BioRad), and reactions consisted of $2 \mu \mathrm{l}$ of cDNA template, $10 \mu \mathrm{l}$ of SsoFast EvaGreen supermix (BioRad), and $0.1 \mu \mathrm{M}$ forward and reverse primers (Table 1 ) in a final volume of $20 \mu \mathrm{l}$. The cycling conditions were $95^{\circ} \mathrm{C}$ for $4 \mathrm{~min}$ followed by 40 cycles of $30 \mathrm{~s}$ at $95^{\circ} \mathrm{C}, 30 \mathrm{~s}$ at $58^{\circ} \mathrm{C}$, and $30 \mathrm{~s}$ at $72^{\circ} \mathrm{C}$. Melt curve analysis was conducted at the end of each reaction to check for primer-dimer formation and ensure gene-specific product amplification. The amplification efficiency of each primer set was tested using a dilution series of infected wheat cDNA in which over $80 \%$ amplification efficiency was obtained for all primer sets. The stability of two reference genes (Tef and Act) was verified using the geNorm program (Vandesompele et al. 2002). These genes were used to generate a normalization factor for each cDNA sample. The normalized expression of each gene of interest was calculated relative to noninoculated control after the normalization factor of $\Delta \mathrm{CT}$ (Ct treatment$\mathrm{Ct}$ control). Averages from three biological replicates for each time point were used.

Microscopic analysis of $\boldsymbol{P}$. graminis $\mathbf{f}$. sp. tritici infection structures in leaves infiltrated with 2-deoxy-D-glucose. The compound 2-deoxy-D-glucose (DDG) (Sigma, Oakville, Ontario, Canada) was dissolved in double-distilled $\mathrm{H}_{2} \mathrm{O}$ and adjusted to a concentration of $5 \times 10^{-4} \mathrm{M}$. The DDG solution was then infiltrated into the first leaves of 7-day-old plants using a Hagborg device equipped with a 3-ml syringe and a 30-gauge needle (Hagborg 1970). For control plants, leaves were infiltrated with double-distilled $\mathrm{H}_{2} \mathrm{O}$. Fungal inoculation was conducted $24 \mathrm{~h}$ after the infiltration, when the infiltrated leaf area no longer appeared water soaked. For microscopic visualization of $P$. graminis f. sp. tritici germ tubes and appressorium, fresh collected leaves were fixed in ethanol/tricholoromethane $(3: 1, \mathrm{vol} / \mathrm{vol})$ solution containing $0.15 \%$ trichloroacetic acid for $24 \mathrm{~h}$ and then stained with $0.1 \%$ aniline blue in $150 \mathrm{mM} \mathrm{H}_{2} \mathrm{HPO}_{4}(\mathrm{pH} 9.5)$ for $30 \mathrm{~min}$. Samples were mounted on a microscope slide and $P$. graminis f. sp. tritici surface infection structures were examined through epifluorescent illumination. The presence of intercellular structures of $P$. graminis $\mathrm{f} . \mathrm{sp}$. tritici was examined in the same leaf segment using the method of Uvitex2B staining described above. Counting of infection sites with P. graminis f. sp. tritici infection structures was conducted on 10 leaf segments $(2 \mathrm{~cm}$ in length) per flat and three flats were included for each time point. The experiment was repeated twice.

\section{RESULTS}

To minimize genetic variation in the wheat host, near-isogenic lines (NILs) varying only in the $S r$ gene they carried were used in this study. Three $P$. graminis f. sp. tritici races (MCCFC, RCCDM, and RHTSC) were inoculated onto seedlings of the susceptible LMPG parent and the NILs carrying $\mathrm{Sr} 6, \mathrm{Sr} 24, \mathrm{Sr} 30$, or $\mathrm{Sr} 36$. The resulting virulence phenotypes are summarized in Table 2 . IT 0 was found in LMPG-Sr36 inoculated with $P$. graminis f. sp. tritici races MCCFC or RCCDM. Two incompatible interactions, Sr6-MCCFC and Sr6-RCCDM, produced IT 0;1. LMPG NILs carrying Sr24 or $S r 30$ were less resistant and produced incompatible IT 2 in interactions of Sr24-MCCFC, Sr24-RHTSC, Sr30-MCCFC, and Sr30-RCCDM. The remaining interactions produced susceptible ITs and were all classified as IT 3 to 4 based on production of large uredinia and the absence of hypersensitive flecks or necrosis.

Significant differences in the development of $P$. graminis $\mathrm{f}$. sp. tritici in various ITs were observed (Fig. 1). In interactions producing the immune IT 0 response (Sr36-MCCFC and Sr36-RCCDM), intercellular fungal structures (including substomatal vesicle, infection

TABLE 2. Infection types (IT) caused by Puccinia graminis f. sp. tritici races on LMPG isogenic lines carrying $\mathrm{Sr} 6, \mathrm{Sr} 24, \mathrm{Sr} 30$, or $\mathrm{Sr} 36^{\mathrm{z}}$

\begin{tabular}{lccccc}
\hline Race & LMPG-Sr6 & LMPG-Sr24 & LMPG-Sr30 & LMPG-Sr36 & LMPG \\
\hline $\begin{array}{c}\text { P. graminis } \\
\text { MCCFC }\end{array}$ & $0 ; 1$ & 2 & 2 & 0 & $3-4$ \\
$\begin{array}{c}P \text {. graminis } \\
\text { RCCDM }\end{array}$ & $0 ; 1$ & $3-4$ & 2 & 0 & $3-4$ \\
$\begin{array}{c}\text { P. graminis } \\
\text { RHTSC }\end{array}$ & $3-4$ & 2 & $3-4$ & $3-4$ & $3-4$ \\
\hline
\end{tabular}

${ }^{\mathrm{z}}$ IT $0=$ no macroscopic sign of infection or only a few faint flecks, IT $0 ; 1=$ small uredinia surrounded by necrosis, IT $2=$ small- to medium-sized uredinia surrounded by chlorosis, and IT 3-4 = large uredinia without chlorosis or necrosis.

TABLE 1. Polymerase chain reaction (PCR) primers used to assay gene expression by reverse-transcription quantitative PCR

\begin{tabular}{|c|c|c|c|c|c|c|c|}
\hline Gene & $\begin{array}{c}\text { Accession } \\
\text { number }\end{array}$ & Source & Web links & Primers $\left(5^{\prime}-3^{\prime}\right)^{\mathrm{y}}$ & $\begin{array}{c}\mathrm{Tm} \\
\left({ }^{\circ} \mathrm{C}\right)^{\mathrm{z}}\end{array}$ & $\begin{array}{l}\text { Size } \\
\text { (bp) }\end{array}$ & $\begin{array}{c}\text { Gene } \\
\text { description }\end{array}$ \\
\hline$C S$ & TC439473 & $\begin{array}{l}\text { Plant gene } \\
\text { index }\end{array}$ & $\begin{array}{l}\text { ftp://occams.dfci.harvard.edu/pub/bio/tgi/data/ } \\
\text { Triticum_aestivum/ }\end{array}$ & $\begin{array}{l}\text { Fw: CGTAGCCAAGGCCATAAGAG } \\
\text { Rv: CTGGGGTTCATTTGTCGAGT }\end{array}$ & 58 & 109 & Callose synthase \\
\hline Tef & M90077 & GenBank & http://www.ncbi.nlm.nih.gov/nuccore/M90077 & $\begin{array}{l}\text { Fw: ATGGTTGTGGAGACCTTTGC } \\
\text { Rv: TGGGTCCTTCTTCTCCACAC }\end{array}$ & 58 & 111 & $\begin{array}{l}\text { Elongation factor } 1 \\
\text { (reference gene) }\end{array}$ \\
\hline Act & AB181991 & GenBank & http://www.ncbi.nlm.nih.gov/nuccore/AB181991 & $\begin{array}{l}\text { Fw: GCGGTCGAACAACTGGTATT } \\
\text { Rv: GGTCCAAACGAAGGATAGCA }\end{array}$ & $\begin{array}{l}58 \\
\cdots\end{array}$ & $\begin{array}{c}105 \\
\ldots\end{array}$ & $\begin{array}{c}\text { Actin (reference gene) } \\
\ldots\end{array}$ \\
\hline
\end{tabular}

${ }^{\mathrm{y}} \mathrm{Fw}=$ forward and $\mathrm{Rv}=$ reverse.

$\mathrm{z} \mathrm{Tm}=$ temperature. 
hyphae, haustoria mother cell, and haustoria) were rarely produced from 5 to 10 DAI (Figs. 1A to C). However, P. graminis f. sp. tritici infection sites containing these infection structures were common in interactions producing highly resistant IT $0 ; 1$, moderately resistant IT 2, or susceptible IT 3-4 pustules (Figs. 1D to L). Hyphal growth was faster with a higher level of branching from 5 to 10 DAI in IT 2 interactions (Figs. 1E and F) compared with interactions producing IT $0 ; 1$ (Figs. $1 \mathrm{H}$ and I). The most rapid growth of $P$. graminis f. sp. tritici colonies was found in interactions producing susceptible IT 3-4 (Figs. $1 \mathrm{~J}$ to $\mathrm{L}$ ). Autofluorescence, indicating cell necrosis, was common in wheat mesophyll cells adjacent to $P$. graminis f. sp. tritici haustorial mother cells in interactions producing IT 0;1 and IT 2 but it was not observed in interactions producing IT 3-4.
Infection sites showing callose deposition, HR, and cellular lignification were investigated in leaves sampled from 1 to $4 \mathrm{DAI}$ (Table 3). In two incompatible interactions of $S r 36$ producing IT 0 , P. graminis f. sp. tritici infection sites showing callose deposition were first detected at $1 \mathrm{DAI}$ and became more common from 2 to 4 DAI. Infection sites showing HR and cellular lignification were also found in interactions producing IT 0 , although at a very low frequency. No callose deposition was found in incompatible interactions of Sr6, Sr24, or Sr30. P. graminis f. sp. tritici infection sites showing HR and cellular lignification were common in interactions producing IT $0 ; 1$ or IT 2. In two incompatible interactions producing IT 0;1 (Sr6-MCCFC and Sr6-RCCDM), P. graminis f. sp. tritici infection sites showing HR and cellular lignification were first observed at 1 DAI. They were not



Fig. 1. Representative cellular responses illustrating various infection types during Puccinia graminis $\mathrm{f}$. sp. tritici infection of LMPG near-isogenic lines carrying $\operatorname{Sr} 6, \operatorname{Sr} 24, \operatorname{Sr} 30$, or $\operatorname{Sr} 36$. A to C, Infection type (IT) 0 was represented by $\operatorname{Sr} 36-\mathrm{MCCFC}$ and $\operatorname{Sr} 36-\mathrm{RCCDM}$; D to F, IT 0;1 was represented by $\operatorname{Sr} 6-\mathrm{MCCFC}$ and Sr6-RCCDM; G to I, IT 2 was represented by Sr24-RHTSC, Sr30-MCCFC, Sr30-RCCDM; and J to L, IT 3-4 was represented by Sr6-RHTSC, Sr24-MCCFC, Sr24-RCCDM, Sr30-RHTSC, LMPG-MCCFC, LMPG-RCCDM, and LMPG-RHTSC. Ap = appressorium, Gt = germ tube, IH = intercellular infection hyphae, and $\mathrm{U}=$ urediniospores; arrow pointed at necrotic cells emitting red autofluorescence. Scale bar is $10 \mu \mathrm{m}$.

TABLE 3. Number of infection sites showing host defense responses in LMPG near-isogenic lines carrying Sr6, Sr24, Sr30, or Sr36 after inoculations with different races of Puccinia graminis f. sp. tritici ${ }^{\mathrm{y}}$

\begin{tabular}{|c|c|c|c|c|c|c|c|c|c|c|c|c|c|}
\hline \multirow[b]{2}{*}{$\mathrm{IT}^{\mathrm{z}}$} & \multirow[b]{2}{*}{ Treatment } & \multicolumn{3}{|c|}{$1 \mathrm{DAI}$} & \multicolumn{3}{|c|}{$2 \mathrm{DAI}$} & \multicolumn{3}{|c|}{3 DAI } & \multicolumn{3}{|c|}{4 DAI } \\
\hline & & Callose & HR & Lignin & Callose & $\mathrm{HR}$ & Lignin & Callose & HR & Lignin & Callose & HR & Lignin \\
\hline 0 & Sr36-MCCFC & $32 \pm 12$ & $5 \pm 3$ & $3 \pm 1$ & $109 \pm 15$ & $10 \pm 5$ & $8 \pm 4$ & $105 \pm 15$ & $10 \pm 4$ & $7 \pm 3$ & $125 \pm 25$ & $11 \pm 5$ & $8 \pm 5$ \\
\hline 0 & Sr36-RCCDM & $28 \pm 6$ & $3 \pm 2$ & $2 \pm 1$ & $115 \pm 25$ & $9 \pm 4$ & $8 \pm 2$ & $109 \pm 12$ & $12 \pm 3$ & $13 \pm 4$ & $115 \pm 21$ & $13 \pm 3$ & $12 \pm 4$ \\
\hline $0 ; 1$ & Sr6-MCCFC & - & 35 & 44 & - & $104 \pm 13$ & $110 \pm 25$ & - & $115 \pm 9$ & $101 \pm 15$ & - & $101 \pm 14$ & $97 \pm 3$ \\
\hline $0 ; 1$ & Sr6-RCCDM & - & 41 & 31 & - & $125 \pm 24$ & $109 \pm 15$ & - & $114 \pm 13$ & $97 \pm 4$ & - & $97 \pm 16$ & $105 \pm 14$ \\
\hline 2 & Sr24-MCCFC & - & - & - & - & $65 \pm 12$ & $52 \pm 10$ & - & $109 \pm 15$ & $115 \pm 6$ & - & $101 \pm 29$ & $97 \pm 12$ \\
\hline 2 & Sr24-RHTSC & - & - & - & - & $55 \pm 15$ & $45 \pm 9$ & - & $99 \pm 11$ & $84 \pm 11$ & - & $105 \pm 15$ & $95 \pm 6$ \\
\hline 2 & Sr30-MCCFC & - & - & - & - & $62 \pm 20$ & $55 \pm 13$ & - & $87 \pm 13$ & $86 \pm 19$ & - & $85 \pm 13$ & $87 \pm 20$ \\
\hline 2 & Sr30-RCCDM & - & - & - & - & $68 \pm 12$ & $49 \pm 10$ & - & $85 \pm 20$ & $79 \pm 6$ & - & $79 \pm 10$ & $75 \pm 12$ \\
\hline $3-4$ & Sr6-RHTSC & - & - & - & - & - & - & - & - & - & - & - & - \\
\hline $3-4$ & Sr24-RCCDM & - & - & - & - & - & - & - & - & - & - & - & - \\
\hline $3-4$ & Sr30-RHTSC & - & - & - & - & - & - & - & - & - & - & - & - \\
\hline $3-4$ & Sr36-RHTSC & - & - & - & - & - & - & - & - & - & - & - & - \\
\hline $3-4$ & LMPG-MCCFC & - & - & - & - & - & - & - & - & - & - & - & - \\
\hline $3-4$ & LMPG-RCCDM & - & - & - & - & - & - & - & - & - & - & - & - \\
\hline $3-4$ & LMPG-RHTSC & - & - & - & - & - & - & - & - & - & - & - & - \\
\hline
\end{tabular}

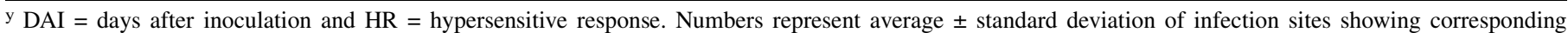
defense response per leaf segments derived from 10 leaf segments ( $2 \mathrm{~cm}$ in length) per pot; three pots were included per treatment; - represents the absence of corresponding host defense response.

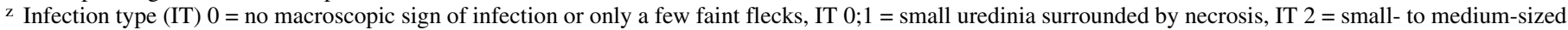
uredinia surrounded by chlorosis, and IT 3-4 = large uredinia without chlorosis or necrosis. 
found in incompatible interactions producing IT 2 (Sr24-RHTSC, Sr30-MCCFC, and Sr30-RCCDM) until 2 DAI. No callose deposition, $\mathrm{HR}$, or cellular lignification was found in any compatible interaction (IT 3-4).

A clear differential response of callose deposition was observed in LMPG-Sr36 inoculated with $P$. graminis $\mathrm{f}$. sp. tritici races MCCFC (IT 0) or RHTSC (IT 3-4) (Fig. 2). In LMPG-Sr36 inoculated with avirulent $P$. graminis f. sp. tritici race MCCFC (IT 0), callose deposition was induced in wheat guard cells at 1 DAI and initially localized in an area of the cell adjacent to the $P$. graminis f. sp. tritici appressorium (Fig. 2A). Fluorescence, indicating callose deposition, intensified in wheat guard cells associated with a $P$. graminis f. sp. tritici appressorium at 2 and 3 DAI (Figs. 2B and C) and surrounded the $P$. graminis f. sp. tritici appressorium at 4 DAI at most infection sites. In comparison, there was no callose deposition in leaves of LMPG-Sr36 inoculated with virulent $P$. graminis $\mathrm{f}$. sp. tritici race RHTSC (IT 3-4; Figures 2E to H) or in compatible or incompatible interactions involving $\mathrm{Sr} 6, \mathrm{Sr} 24$, or $\mathrm{Sr} 30$ (pictures not shown). The occurrence of an HR and cellular lignification was also investigated in leaves of LMPG NILs sampled at 5 and 7 DAI (Fig. 3). In interactions producing IT 0 , a region of cells showing an HR and cellular lignification was occasionally observed and only involved a few host cell cells (Fig. 3A to D). In comparison, the induction of $\mathrm{HR}$ and cellular lignification was stronger in interactions producing IT $0 ; 1$ or IT 2 . The region of cells showing these defense responses was more diffuse and the response was less intense in interactions producing IT 2 compared with IT 0;1 (Fig. 3E to 3L). No wheat cells showing HR and cellular lignification were found in interactions producing susceptible IT 3-4 at 5 and 7 DAI (Fig. 3M to P).

Host genetic background has been shown to affect the expression of $\mathrm{Sr}$ genes (Roelfs et al. 1992); thus, we examined whether the deposition of callose in interactions producing IT 0 is related to the host background. Wheat lines carrying Sr36 in the Prelude and W2691 backgrounds were also inoculated with $P$. graminis f. sp. tritici races MCCFC (IT 0) and RHTSC (IT 3-4), and a line carrying $\mathrm{Sr} 5$ in an LMPG background was inoculated with $P$. graminis $\mathrm{f}$. sp. tritici races HKCJC (IT 0) and MCCFC (IT 3-4). In all lines, callose was induced in wheat guard cells within $1 \mathrm{DAI}$ after the inoculation with corresponding avirulent $P$. graminis f. sp. tritici races (Fig. 4), and intercellular fungal structures were rarely produced at infection sites (pictures not shown). Callose deposition was not induced in these wheat lines when inoculated with virulent $P$. graminis $\mathrm{f}$. sp. tritici races. Furthermore, the resistance response of LMPG-Sr36 to P. graminis $\mathrm{f}$. sp. tritici race QTHJF, which produces the highly resistant IT of $0 ; 1$, was also studied (Fig. 5). In this interaction, callose deposition was induced in epidermal cells but not in guard cells at 1 DAI and $P$. graminis $\mathrm{f}$. sp. tritici race QTHJF was also able to develop intercellular infection structures and cause cell necrosis at 5 and 10 DAI.

We conducted an RT-qPCR analysis to study the expression of genes involved in callose synthesis and cellular lignification in LMPG NILs carrying Sr6, Sr30, or Sr36 inoculated with $P$. graminis

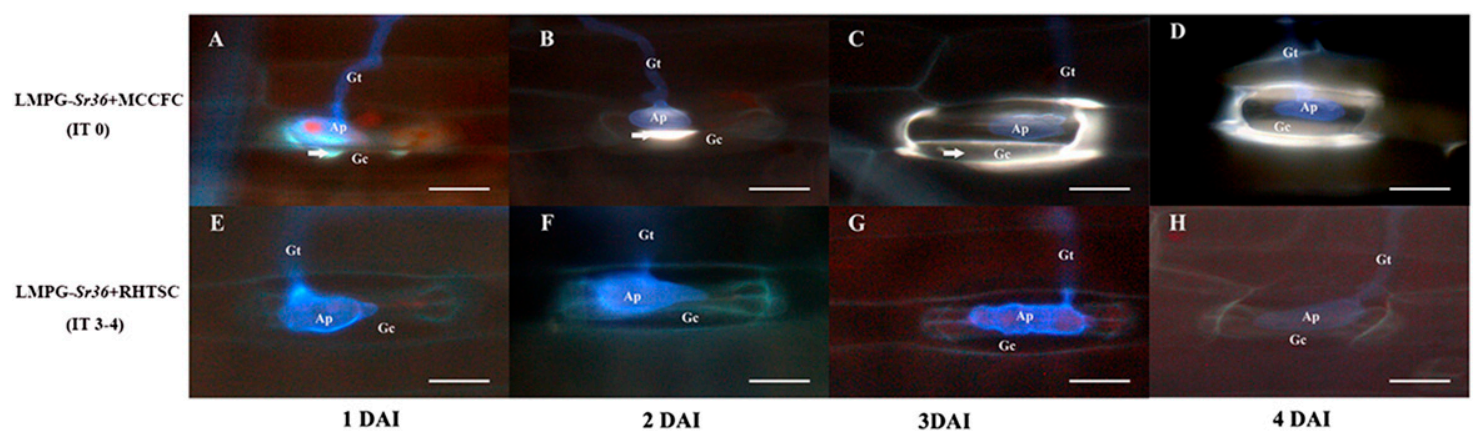

Fig. 2. Deposition of callose during the infection of Puccinia graminis f. sp. tritici on LMPG-Sr36. A to D, LMPG infected with $P$. graminis f. sp. tritici race MCCFC (IT 0) at 1 to 4 days after inoculation (DAI) and $\mathbf{E}$ to $\mathbf{H}$, LMPG infected with P. graminis f. sp. tritici race RHTSC (IT 3 to 4 ) at 1 to 4 DAI. Arrows indicate regions of cell with callose deposition. $\mathrm{Gt}=$ germ tube, $\mathrm{Ap}=$ appressorium, and Gc $=$ guard cell. Scale bar is $10 \mu \mathrm{m}$.



Fig. 3. Occurrence of hypersensitive response and cellular lignification in different infection types generated from LMPG near-isogenic lines inoculated with different races of Puccinia graminis f. sp. tritici. A to D, Infection type (IT) 0 was represented by Sr36-MCCFC and Sr36-RCCDM; E to H, IT 1 was represented by $S r 6-$ MCCFC and Sr6-RCCDM; I to L, IT 2 was represented by Sr24-RHTSC, Sr30-MCCFC, and Sr30-RCCDM; and M to P, IT 3-4 was represented by Sr6-RHTSC, Sr24-MCCFC, Sr24-RCCDM, Sr30-RHTSC, LMPG-MCCFC, LMPG-RCCDM, and LMPG-RHTSC. Arrows pointed at the region of cells showing hypersensitive response (trypan blue staining) or cellular lignification (Phloroglucino-HCl staining). Scale bar $=25 \mu \mathrm{m}$. 
f. sp. tritici races MCCFC or RHTSC (Fig. 6). The transcript level of callose synthase $(C S)$ increased starting at 1 DAI only in leaves of LMPG-Sr36 inoculated with race MCCFC (IT 0) and its expression peaked at 3 DAI (3.45-fold). No significant upregulation of $C S$ transcripts was found in compatible or incompatible interactions involving $\mathrm{Sr} 6$ or $\mathrm{Sr} 30$, or in LMPG inoculated with $P$. graminis $\mathrm{f} . \mathrm{sp}$. tritici races MCCFC, RCCDM, or RHTSC. Transcript encoding phenylalanine ammonia lyase $(\mathrm{Pal})$ showed a different pattern of expression. Pal expression increased in Sr6-MCCFC (IT 0;1) from 1 to 3 DAI. The expression of $\mathrm{Pal}$ was also observed in Sr30-MCCFC (IT 2) but its onset was delayed and still increasing at 4 DAI. A small increase in Pal expression was also observed in

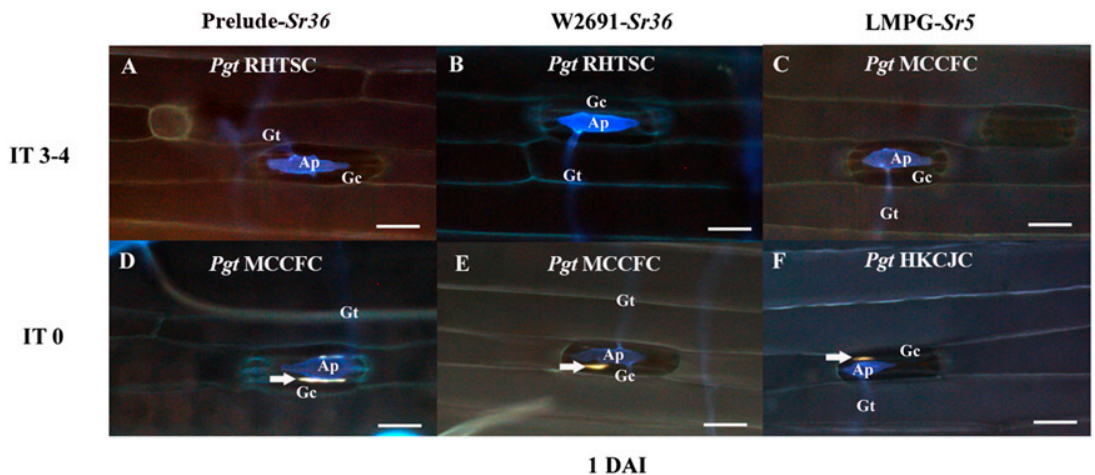

Fig. 4. Deposition of callose during the infection Puccinia graminis f. sp. tritici on Prelude-Sr36, W2691-Sr36 and LMPG-Sr5. Infection type (IT) 3-4 was represented by A, Prelude-Sr36 and B, W2691-Sr36 inoculated with P. graminis f. sp. tritici race RHTSC; and C, LMPGSr5 inoculated with P. graminis f. sp. tritici race MCCFC. IT 0 was represented by D, Prelude-Sr36 and E, W2691-Sr36 inoculated with P. graminis f. sp. tritici race MCCFC; and F, LMPG-Sr5 inoculated with $P$. graminis f. sp. tritici race HKCJC. Arrows pointed at regions of cell with callose deposition. Scale bar $=10 \mu \mathrm{m}$.

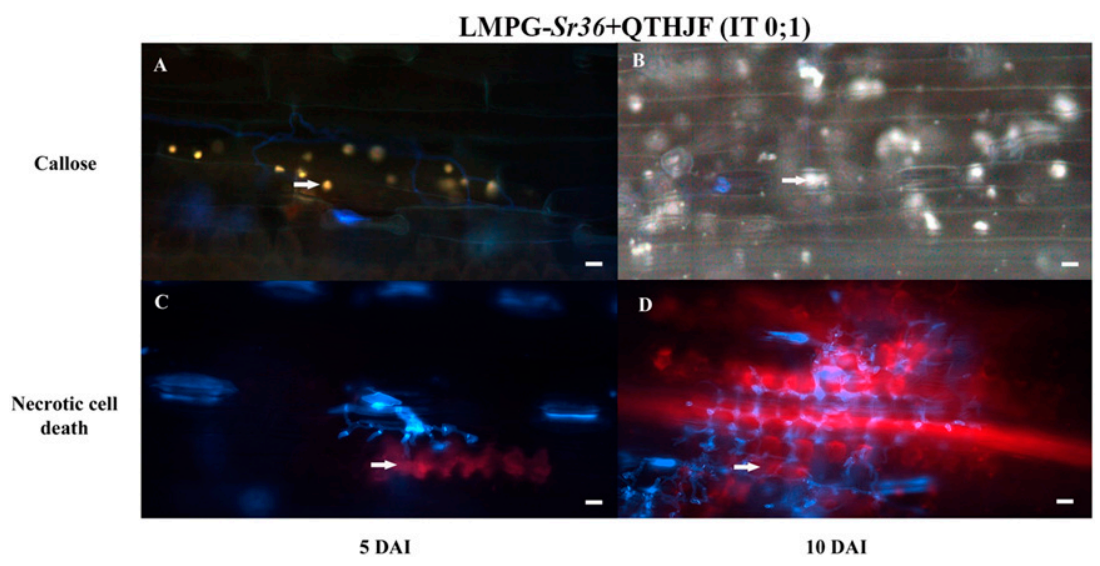

Fig. 5. Occurrence of callose deposition and necrotic cell death during the infection Puccinia graminis f. sp. tritici race QTHJF on LMPG-Sr36. Arrows pointed at $\mathbf{A}$ and $\mathbf{B}$, regions of cell with callose deposition and $\mathbf{C}$ and $\mathbf{D}$, the autofluorescence from necrotic cells. Scale bar $=10 \mu \mathrm{m}$.

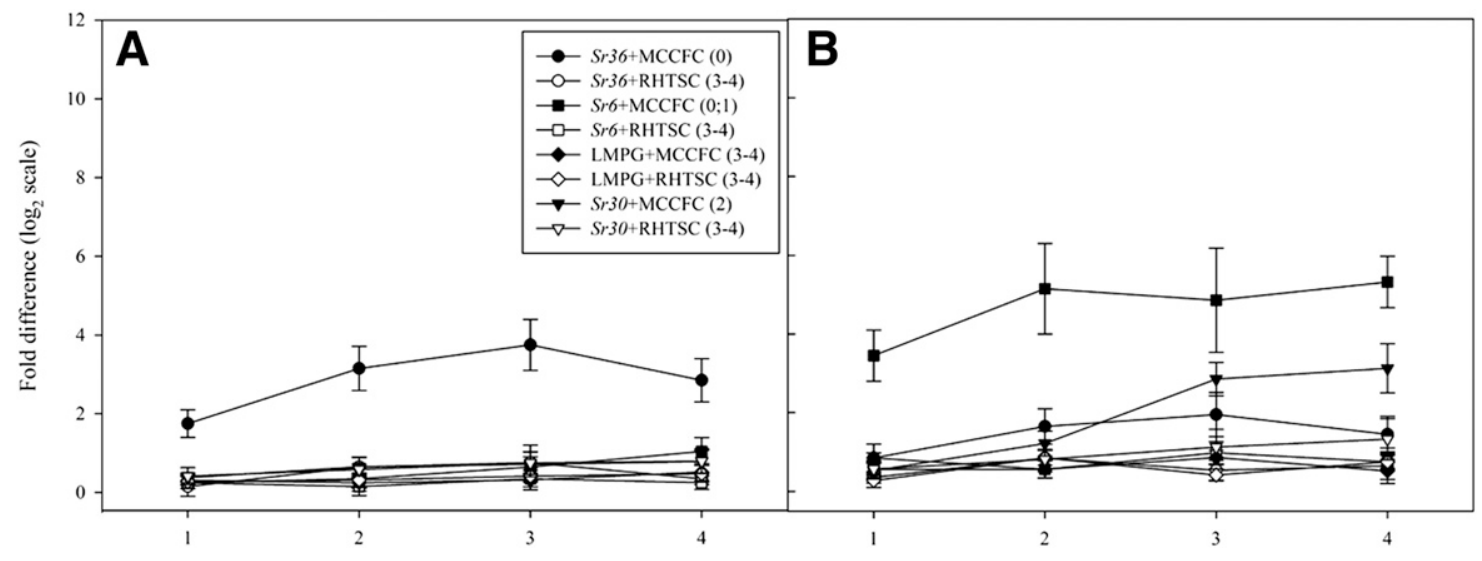

Fig. 6. Changes in transcript levels of wheat genes encoding A, callose synthase and B, phenylalanine ammonia lyase in LMPG near-isogenic lines carrying Sr6, Sr30, or Sr36 after inoculation with Puccinia graminis f. sp. tritici race MCCFC or RHTSC. Plant samples were taken at 24-h intervals post inoculation (X axis). Real-time polymerase chain reaction was used to quantify expression of each gene. P. graminis f. sp. tritici elongation factor and actin were used as the internal

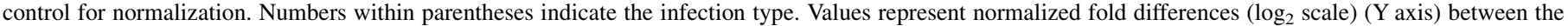
inoculated and corresponding noninoculated treatment. Bars indicate standard errors. 
Sr36-MCCFC (IT 0) at 2 and 3 DAI but it is less elevated compared with interactions producing IT 0;1 and IT 2. In the susceptible IT 3-4, there was no increase in the expression of Pal transcripts.

The effect of inhibition of callose deposition was investigated using DDG, a suppressor of callose biosynthesis (Sivaguru et al. 2000). The application of a $0.5-\mu \mathrm{M}$ solution of DDG did not affect the germination of $P$. graminis $\mathrm{f}$. sp. tritici urediniospores and germ tube growth (data not shown). LMPG-Sr36 plants were infiltrated with DDG $24 \mathrm{~h}$ prior to inoculation with $P$. graminis $\mathrm{f}$. $\mathrm{sp}$. tritici race MCCFC. It resulted in a statistically significant increase of $P$. graminis f. sp. tritici colonies producing substomatal vesicles and haustorial mother cells, reaching $25 \%$ at 5 DAI. In the water control treatment, infection often ceased after the formation of an appressorium and only a small portion of infection sites managed to produce substomatal vesicles and haustorial mother cells (less than $5 \%$ of the sites) at 5 DAI (Table 4). In the interaction of Sr36-RHTSC (IT 3-4), substomatal vesicles and haustorial mother cells were found in the majority of $P$. graminis f. sp. tritici infection sites at 1, 3, and 5 DAI (75, 93, and 95\%, respectively), and infiltration of DDG had no effect on the development of $P$. graminis f. sp. tritici infection structures. Similarly, the majority of P. graminis f. sp. tritici colonies produced substomatal vesicles and haustorial mother cells in interactions of Sr6-MCCFC, Sr6-RHTSC, LMPG-MCCFC, and LMPG-RHTSC. No significant differences in the development of $P$. graminis $\mathrm{f}$. sp. tritici infection structures were found in these interactions when plants were infiltrated with either water or DDG.

\section{DISCUSSION}

Microscopic analyses of fungal growth in the host, plant histology, pharmacological inhibition of host responses, and RTqPCR analyses were used to uncover morphological and molecular responses of host-pathogen interactions between races of $P$. graminis f. sp. tritici and wheat lines carrying different racespecific $S r$ genes. The molecular basis of the interaction between biotrophic fungal pathogens and their hosts involves the pathogen production and release of effectors which either elicit a response facilitating growth of the fungus (virulence) or a response inhibiting growth of the fungus (Avr). The response is dictated by the nature of plant host resistance $(R)$ genes (Ali and Bakkeren 2011; Donofrio and Raman 2012). Although P. graminis f. sp. tritici effectors and products of corresponding wheat $R$ genes are only beginning to be identified, the data presented in this study suggested that the recognition of $P$. graminis $\mathrm{f}$. sp. tritici effectors could take place at different stages of the infection process. Two distinct categories of responses were uncovered, one mediated after the production of haustoria and the other elicited at earlier stages in the absence of haustoria. The novel aspects of these interaction types are interpreted in the context of effector production, delivery, and response.

The resistance mediated by $\mathrm{Sr} 6, \mathrm{Sr} 24$, or $\mathrm{Sr} 30$ was associated with defense responses induced in mesophyll cells and development of $P$. graminis f. sp. tritici haustoria. Although the specifics of each race-host interaction varied, all produced an HR and cellular lignification. This suggests that these defense responses are commonly induced when pathogen penetration and haustorial formation have occurred. Many rust fungi produce haustoria that develop a close contact with the plant cell membrane (Catanzariti et al. 2006; Garnica et al. 2014). Investigations using the rust fungi M. lini and Uromyces fabae indicated that effectors produced in haustoria were transported into the host cytoplasm (Dodds et al. 2004; Kemen et al. 2005). Further, expressed secreted proteins from an $M$. lini haustorium-specific cDNA library were found to be highly enriched for Avr factors (Catanzariti et al. 2006), indicating a large number of effectors potentially produced in rust haustoria. It is likely that effectors produced by $P$. graminis f. sp. tritici haustoria contribute to the elicitation of host defense responses in wheat lines carrying resistance genes $\mathrm{Sr} 6, \mathrm{Sr} 24$, or $\mathrm{Sr} 30$ as well as in some interactions involving $\mathrm{Sr} 36$.

It has been hypothesized that the induction of the HR in resistance mediated by race-specific rust resistance genes can effectively inhibit pathogen infection (Hammond-Kosack and Jones 1997; Leonard and Szabo 2005). However, observations made in this study show that the HR and cellular lignification are only partially effective and allow a limited growth of $P$. graminis $\mathrm{f}$. sp. tritici in incompatible interactions involving $\mathrm{Sr} 6, \mathrm{Sr} 24$, or $\mathrm{Sr} 30$. This results in a level of fungal growth to form pustule development that ranges from IT $0 ; 1$ to IT 2 . In a separate study, the development of $P$. triticina was only quantitatively reduced by an HR-like response in resistant IT 1 and 2 involving wheat leaf rust resistance gene $L r 2 a, L r 3$, or $L r B$ (Wang et al. 2012). Although an HR was triggered, cell death, antifungal compounds, and cellular lignification are apparently not generated quickly enough or not in sufficient

TABLE 4. Effect of inhibition of callose deposition on the development of three Puccinia graminis f. sp. tritici infection stages after inoculation on LMPG NILs carrying $\operatorname{Sr} 6, \operatorname{Sr} 24, \operatorname{Sr} 30$, or $\operatorname{Sr} 36$

\begin{tabular}{|c|c|c|c|c|c|c|c|c|c|c|}
\hline \multirow[b]{3}{*}{ Treatment, interactions ${ }^{y}$} & \multirow[b]{3}{*}{$\mathrm{IT}^{\mathrm{z}}$} & \multicolumn{9}{|c|}{ Infection sites $(\%)$ with $^{\mathrm{x}}$} \\
\hline & & \multicolumn{3}{|c|}{$1 \mathrm{DAI}$} & \multicolumn{3}{|c|}{3 DAI } & \multicolumn{3}{|c|}{$5 \mathrm{DAI}$} \\
\hline & & Ap & Ap + SSV & $\mathrm{AP}+\mathrm{SSV}+\mathrm{IH}$ & Ap & Ap + SSV & $\mathrm{AP}+\mathrm{SSV}+\mathrm{IH}$ & Ap & $\mathrm{Ap}+\mathrm{SSV}$ & $\mathrm{AP}+\mathrm{SSV}+\mathrm{IH}$ \\
\hline Sr36-MCCFC & 0 & $93 \mathrm{~A}$ & $6 \mathrm{~A}$ & $0 \mathrm{~A}$ & $93 \mathrm{~A}$ & $4.2 \mathrm{~A}$ & $3 \mathrm{~A}$ & $93 \mathrm{~A}$ & $3 \mathrm{~A}$ & $4 \mathrm{~A}$ \\
\hline Sr36-RHTSC & $3-4$ & $6 \mathrm{~B}$ & $18 \mathrm{~B}$ & $75 \mathrm{~B}$ & $3 \mathrm{~B}$ & $3.4 \mathrm{~A}$ & $93 \mathrm{~B}$ & $2 \mathrm{~B}$ & $3 \mathrm{~A}$ & $96 \mathrm{~B}$ \\
\hline Sr6-MCCFC & $0 ; 1$ & $10 \mathrm{~B}$ & $23 \mathrm{~B}$ & $65 \mathrm{~B}$ & $5 \mathrm{~B}$ & $6.2 \mathrm{~A}$ & $89 \mathrm{~B}$ & $4 \mathrm{~B}$ & $6 \mathrm{~A}$ & $91 \mathrm{~B}$ \\
\hline Sr6-RHTSC & $3-4$ & $7 \mathrm{~B}$ & $21 \mathrm{~B}$ & $71 \mathrm{~B}$ & $5 \mathrm{~B}$ & $4.8 \mathrm{~A}$ & $91 \mathrm{~B}$ & $2 \mathrm{~B}$ & $4 \mathrm{~A}$ & $94 \mathrm{~B}$ \\
\hline \multicolumn{11}{|l|}{$\operatorname{DDG}\left(5.0 \times 10^{-3} \mathrm{M}\right)$} \\
\hline Sr36-MCCFC & 0 & $71 \mathrm{C}$ & $9 \mathrm{~A}$ & $19 \mathrm{C}$ & $69 \mathrm{C}$ & $6.7 \mathrm{~A}$ & $24 \mathrm{C}$ & $69 \mathrm{C}$ & $6 \mathrm{~A}$ & $25 \mathrm{C}$ \\
\hline Sr36-RHTSC & $3-4$ & $8 \mathrm{~B}$ & $16 \mathrm{~B}$ & $75 \mathrm{~B}$ & $4 \mathrm{~B}$ & $4.1 \mathrm{~A}$ & $91 \mathrm{~B}$ & $3 \mathrm{~B}$ & $4 \mathrm{~A}$ & $93 \mathrm{~B}$ \\
\hline Sr6-MCCFC & $0 ; 1$ & $11 \mathrm{~B}$ & $24 \mathrm{~B}$ & $64 \mathrm{~B}$ & $5 \mathrm{~B}$ & $8.2 \mathrm{~A}$ & $87 \mathrm{~B}$ & $3 \mathrm{~B}$ & $6 \mathrm{~A}$ & $91 \mathrm{~B}$ \\
\hline Sr6-RHTSC & $3-4$ & $9 \mathrm{~B}$ & $20 \mathrm{~B}$ & $70 \mathrm{~B}$ & $5 \mathrm{~B}$ & $5.1 \mathrm{~A}$ & $90 \mathrm{~B}$ & $2 \mathrm{~B}$ & $3 \mathrm{~A}$ & $95 \mathrm{~B}$ \\
\hline LMPG-MCCFC & $3-4$ & $8 \mathrm{~B}$ & $18 \mathrm{~B}$ & $72 \mathrm{~B}$ & $6 \mathrm{~B}$ & $4.3 \mathrm{~A}$ & $90 \mathrm{~B}$ & $4 \mathrm{~B}$ & $6 \mathrm{~A}$ & $90 \mathrm{~B}$ \\
\hline LMPG-RHTSC & $3-4$ & $7 \mathrm{~B}$ & $21 \mathrm{~B}$ & $71 \mathrm{~B}$ & $4 \mathrm{~B}$ & $2.1 \mathrm{~A}$ & $95 \mathrm{~B}$ & $3 \mathrm{~B}$ & $2 \mathrm{~A}$ & $95 \mathrm{~B}$ \\
\hline
\end{tabular}

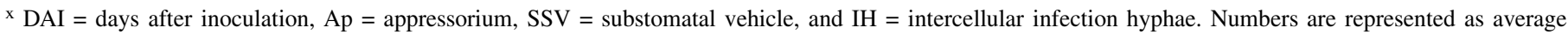
derived from 10 leaf segments per pot; three pots were included per treatment. The same letter following values in each column indicates not significantly different at $P=0.01$ (Fisher's least significant difference). Statistical test was not performed if one value in the column was zero.

y Water (control) or 2-deoxy-D-glucose (DDG) were infiltrated into leaf $24 \mathrm{~h}$ before inoculations using a Hagborg device.

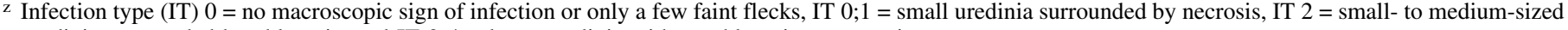
uredinia surrounded by chlorosis, and IT 3-4 = large uredinia without chlorosis or necrosis. 
quantities to completely suppress fungal growth, and rust pathogens were able to obtain sufficient nutrients to sustain limited growth. It is possible that plant responses other than HR are required for an immune reaction, and there is diversity in how fungi adapt to HR and enable continued reproduction.

Both histological and qPCR analysis showed that the expression of the HR and cellular lignification is delayed in the resistance mediated by $S r 24$ or $S r 30$ compared with the resistance mediated by Sr6. Rohringer et al. (1979) also showed variations in the induction of the HR in wheat to $P$. graminis f. sp. tritici infections. Their data indicated that, during incompatible interactions of $\operatorname{Sr} 5$ or $\operatorname{Sr} 6$, host cell necrosis associated with the HR was observed at 1 DAI and it was not detected in plants carrying $S r 22$ until 3 DAI with an avirulent $P$. graminis f. sp. tritici race. It is not yet known whether the timing of the expression of resistance genes or corresponding effector ( $a v r)$ genes is related to levels of resistance mediated by these $\mathrm{Sr}$ genes. Because many effector genes are induced in infection stage-specific waves (Hacquard et al. 2011) and defense responses to effectors are often mediated through $R$ gene products, these data suggest that effectors and corresponding $\mathrm{R}$ proteins interact, triggering different reactions at different stages of the infection as a result of effector expression in distinct waves (Ali and Bakkeren 2011; Rafiqi et al. 2012). These waves may have evolved to target different stages of the plant response pathway. If this is the case, further investigations of $P$. graminis f. sp. tritici-Sr interactions are needed to uncover the molecular details of these different stages in wheat resistance to stem rust.

In contrast to the production of haustoria and induction of an HR mediated by $\mathrm{Sr} 6, \mathrm{Sr} 24$, and $\mathrm{Sr} 30$, the plant responses mediated by $\mathrm{Sr} 36$ or $\mathrm{Sr} 5$ involved the deposition of callose at very early stages of infection. In the interaction between $P$. graminis f. sp. tritici race MCCFC and LMPG-Sr36, the deposition of callose was initially localized in guard cells close to the $P$. graminis f. sp. tritici appressorium. During the infection process on wheat, $P$. graminis $\mathrm{f}$. sp. tritici usually forms an appressorium over the stomatal opening and then produces a penetration peg that passes between guard cells (Leonard and Szabo 2005). The quick induction of callose in host guard cells after the formation of the $P$. graminis f. sp. tritici appressorium suggests that the deposition of callose in the Sr36mediated resistance response is triggered by a prehaustorial recognition-driven mechanism. A similar pattern of callose deposition was also found in Prelude-Sr36, W2691-Sr36, and in LMPG-Sr 5 after inoculations with avirulent $P$. graminis $\mathrm{f}$. sp. tritici races, producing the immune response IT 0 (pictures not shown). This indicates that the response is not a result of the genetic background but, rather, that it is mediated by $\operatorname{Sr} 5$ or $\operatorname{Sr} 36$, both conferring an immune IT. In the interaction between $P$. graminis $\mathrm{f}$. sp. tritici race QTHJF and LMPG-Sr36, which generated a resistant IT $0 ; 1$, both the callose deposition and an HR were observed. In this particular interaction, the deposition of callose was mainly induced in the mesophyll cells and the growth of the fungus was not completely stopped. It is possible that the location of callose deposition in response to the recognition of the pathogen is critical and affects the effectiveness of the resistance mediated by Sr36.

Because $P$. graminis f. sp. tritici is not known to directly penetrate wheat guard cells, the induction of callose in these cells must be a response to signals (possibly effectors) entering or perceived by the plant cell by some means other than haustoria production. Several fungi that do not produce haustoria secrete effectors that enter the plant cell such as the necrotrophic effector ToxA from Pyrenophora tritici (Manning and Ciuffetti 2005) or effectors secreted by Ustilago maydis (Doehlemann et al. 2009). Therefore, it is possible that effectors responsible for eliciting defense responses mediated by $\operatorname{Sr} 5$ or $\operatorname{Sr} 36$ are attached to the surface of appressoria or released from the appressorium without it first penetrating the plant cell. This might be similar to the situation for Rpgl-mediated stem rust resistance in barley, which could be triggered by Puccinia graminis f. sp. tritici urediniospores on the leaf surface before the formation of haustoria. It was suggested that an effector on or released from the spore surface activated this response (Nirmala et al. 2011). The possibility of the induction of a response mediated by $S r 36$ or $S r 5$ through an effector on the fungal surface or released from the appressorium cell surface suggests that the reaction may be mediated through a signal transduction pathway and not involving the entrance of the effector into host cell.

Rowell (1981) found that $P$. graminis f. sp. tritici development often ceased after substomatal vesicles were formed and the production of haustorial mother cells was rare in a wheat differential line carrying $S r 36$ when inoculated with $P$. graminis f. sp. tritici race 151-QSH. It was suggested that the defense mechanism other than the cell necrosis might be involved in the resistance mediated by $S r 36$ because the delay in the $P$. graminis $\mathrm{f}$. sp. tritici infection process was not always associated with the HR of the host cell. In a previous study, the deposition of callose was quickly induced in a Thatcher NIL carrying leaf rust resistance gene ( $L r) L r 9$ when inoculated with a $P$. triticina avirulent race BBBD; callose was not induced in Thatcher NILs carrying resistance gene $L r 2 a, L r 3$, or $L r B$ after inoculations with corresponding avirulent races of $P$. triticina (Wang et al. 2012). $L r 9$ exhibits an IT 0 to corresponding avirulent $P$. triticina races, in which only few or no haustoria are formed and papillae resulting from callose deposition are found at infection sites. Furthermore, a similar prehaustorial resistance was described in the interaction between Triticum monococcum (wild diploid wheat) and $P$. triticina (Anker and Niks 2001). During infections by fungi using direct cell penetration, callose can be deposited in papillae formed beneath infection sites, which provides a physical barrier preventing the penetration of the pathogen (Aist and Bushnell 1991). The papillae-based defense response has been described in interactions between Blumeria graminis and barley as well as between Uromyces vignae and cowpea, where callose deposition resulted in the complete encasement of intercellular fungal structures (Heath 1971; Thordal-Christensen et al. 2000).

Because $P$. graminis f. sp. tritici is not known to directly infect wheat guard cells, callose deposition in the resistance mediated by Sr36 is unlikely an induced response to prevent the penetration of host guard cells. In the fern (Asplenium nidus), callose biosynthesis is an essential component of the mechanism of stomatal pore formation, where the open stomata entirely lack callose whereas the closed stomata show distinct radical fibrillar callose arrays in the external periclinal wall (Apostolakos et al. 2010). It is possible that the increase of callose synthesis in guard cells of LMPG-Sr36 contributes to the closure of stomatal openings to prevent or delay the penetration of $P$. graminis $\mathrm{f}$. sp. tritici through the leaf epidermal surface and the subsequent formation of a substomatal vesicle in the stomatal cavity. The experiments where callose deposition was inhibited by DDG in the LMPG-Sr36 interaction and resulted in an increase in $P$. graminis $\mathrm{f}$. sp. tritici colonies with substomatal vesicles and haustorial mother cells (Table 4) is consistent with this hypothesis.

Callose deposition is typically associated with PAMP-triggered immunity (Nicaise et al. 2009). In our study, the deposition of callose was targeted to guard cells in the resistance response mediated by $\operatorname{Sr} 36$ and $\operatorname{Sr} 5$, which prevented the penetration of $P$. graminis f. sp. tritici through stomata. In interactions between plants and bacteria, several well-defined PAMPs have been shown to induce the stomatal closure in tomato, grape, and Arabidopsis, which involves the activation of a host mitogen-activated protein kinase pathway (Allegre et al. 2009; Melotto et al. 2006). Furthermore, callose deposition is also one of the key defense responses induced in nonhost interactions such as during the infection of rice and purple false brome (Brachypodium distachyon), with cereal rust fungus species ( $P$. graminis f. sp. tritici, P. triticina, and P. striiformis) (Ayliffe et al. 2011, 2013; Figueroa et al. 2013) and during the infection of Arabidopsis thaliana by P. striiformis f. sp. tritici (Cheng et al. 2013). Therefore, we cannot rule out the possibility that the $P$. graminis $\mathrm{f}$. sp. tritici-derived molecules that are recognized by the wheat host may not be effectors 
but membrane-bound or cytoplasmic PAMPs. Further studies, such as an expression analysis of defense genes involved in different signaling pathways during the early stages of the infection process, may provide more insight into the exact defense mechanism during the various described interactions of $P$. graminis $\mathrm{f}$. $\mathrm{sp}$. tritici and its host.

In this study, we demonstrated the occurrence of autofluorescence from necrotic cells undergoing an HR and cellular lignification during incompatible interactions mediated by $\mathrm{Sr} 6, \mathrm{Sr} 24$, and $\mathrm{Sr} 30$. However, these defense responses were insufficient to completely block the growth of $P$. graminis f. sp. tritici and pustules were still produced in these resistant lines. Although resistance mediated by genes $\operatorname{Sr} 6, \operatorname{Sr} 24$, and Sr30 apparently is conditioned by similar mechanisms, the timing of the response varied. A further investigation to study effector waves and their effect on timing of resistance responses is warranted. This study also demonstrated the deposition of callose in wheat guard cells penetrated by $P$. graminis f. sp. tritici during a resistance response mediated by $\mathrm{Sr} 5$ or $\mathrm{Sr} 36$. In these cases, the mechanism triggering callose deposition does not involve the production of haustoria and, therefore, may not involve effectors entering the host cell; rather, this defense response may be mediated by extracellular signals (effectors) activating a signal transduction pathway similar to that activated during other responses involving guard cells such as by PAMPs or during nonhost interactions (Allegre et al. 2009; Melotto et al. 2006). Unraveling these discriminating mechanisms will provide an excellent basis for uncovering the nature of the interaction between effectors and $R$ gene products. Our study revealed that the diversity of responses leading to $P$. graminis $\mathrm{f}$. sp. tritici resistance in wheat are addressable through the investigation of wheat NILs and appropriate stem rust fungus races. This then also provides a basis and direction for future investigations using genomewide transcriptional analyses (through RNA sequencing) to identify $P$. graminis f. sp. tritici effectors and resistance-related genes during various wheat $-P$. graminis $\mathrm{f}$. sp. tritici interactions.

\section{ACKNOWLEDGMENTS}

We thank the Ontario Ministry of Research and Innovation, Agriculture and Agri-Food Canada, and Trent University for their financial support on this project; and T. Zegeye-Gebrehiwot for providing technical assistance in this study.

\section{LITERATURE CITED}

Adam, L., and Somerville, S. C. 1996. Genetic characterization of five powdery mildew disease resistance loci in Arabidopsis thaliana. Plant J. 9:341-356.

Aist, J. R. B., and Bushnell, W. R. 1991:Pages 321-345 in: The Fungal Spore and Disease Initiation in Plants and Animals. G. T. Cole and H. C. Hoch, eds. Plenum, New York.

Ali, S., and Bakkeren, G. 2011. Fungal and oomycete effectors-Strategies to subdue a host. Can. J. Plant Pathol. 33:425-446.

Allegre, M., Heloir, M. C., Trouvelot, S., Daire, X., Pugin, A., Wendehenne, D., and Adrian, M. 2009. Are grapevine stomata involved in the elicitor-induced protection against downy mildew? Mol. Plant-Microbe Interact. 22:977-986.

Anker, C., and Niks, R. 2001. Prehaustorial resistance to the wheat leaf rust fungus, Puccinia triticina, in Triticum monococcum (s.s.). Euphytica 117:209-215.

Apostolakos, P., Livanos, P., Nikolakopoulou, T. L., and Galatis, B. 2010. Callose implication in stomatal opening and closure in the fern Asplenium nidus. New Phytol. 186:623-635.

Ayliffe, M., Devilla, R., Mago, R., White, R., Talbot, M., Pryor, A., and Leung, H. 2011. Non-host resistance of rice to rust pathogens. Mol. Plant-Microbe Interact. 24:1143-1155.

Ayliffe, M., Singh, D., Park, R., Moscou, M., and Pryor, T. 2013. Infection of Brachypodium distachyon with selected grass rust pathogens. Mol. PlantMicrobe Interact. 26:946-957.

Bolton, M. D., Kolmer, J. A., and Garvin, D. F. 2008. Wheat leaf rust caused by Puccinia triticina. Mol. Plant Pathol. 9:563-575.

Bushnell, W. R. 1970. Patterns in the growth, oxygen uptake, and nitrogen content of single colonies of wheat stem rust on wheat leaves. Phytopathology 60:92-99.

Catanzariti, A. M., Dodds, P. N., Lawrence, G. J., Ayliffe, M. A., and Ellis, J. G. 2006. Haustorially expressed secreted proteins from flax rust are highly enriched for avirulence elicitors. Plant Cell 18:243-256.
Cheng, Y. N., Zhang, H. C., Yao, J. N., Han, Q. M., Wang, X. J., Huang, L. L., and Kang, Z. S. 2013. Cytological and molecular characterization of nonhost resistance in Arabidopsis thaliana against wheat stripe rust. Plant Physiol. Biochem. 62:11-18.

Clay, N. K., Adio, A. M., Denoux, C., Jander, G., and Ausubel, F. M. 2009. Glucosinolate metabolites required for an Arabidopsis innate immune response. Science 323:95-101.

Dodds, P. N., Lawrence, G. J., Catanzariti, A. M., Ayliffe, M. A., and Ellis, B. E. 2004. The Melampsora lini AvrL567 avirulence genes are expressed in haustoria and their products are recognized inside plant cells. Plant Cell 16: 755-768.

Doehlemann, G., van der Linde, K., Assmann, D., Schwammbach, D., Hof, A., Mohanty, A., Jackson, D., and Kahmann, R. 2009. Pep1, a secreted effector protein of Ustilago maydis, is required for successful invasion of plant cells. PLoS Pathog. 5(2):e1000290.

Donofrio, N. M., and Raman, V. 2012. Roles and delivery mechanisms of fungal effectors during infection development: Common threads and new directions. Curr. Opin. Microbiol. 15:692-698.

Fetch, T. G., Fetch, J. M., and Xue, A. 2011. Races of Puccinia graminis on barley, oat and wheat in Canada in 2006. Can. J. Plant Pathol. 33:54-60.

Figueroa, M., Alderman, S., Garvin, D. F., and Pfender, W. F. 2013. Infection of Brachypodium distachyon by formae speciales of Puccinia graminis: Early infection events and host-pathogen incompatibility. PLoS One 8:e56857.

Garnica, D. P., Nemri, A., Upadhyaya, N. M., Rathjen, J. P., and Dodds, P. N. 2014. The ins and outs of rust haustoria. PLoS Pathog. 10:e1004329.

Hacquard, S., Joly, D. L., Lin, Y. C., Tisserant, E., Feau, N., Delaruelle, C., Legué, V., Kohler, A., Tanguay, P., Petre, B., Frey, P., Van de Peer, Y., Rouzé, P., Martin, F., Hamelin, R. C., and Duplessis, S. 2012. A comprehensive analysis of genes encoding small secreted proteins identifies candidate effectors in Melampsora larici-populina (Poplar leaf rust). Mol. Plant-Microbe Interact. 25:279-293.

Hagborg, W. A. F. 1970. A device for injecting solutions and suspensions into thin leaves of plants. Can. J. Bot. 48:1135-1136.

Hammond-Kosack, K. E., and Jones, J. D. G. 1997. Plant disease resistance genes. Annu. Rev. Plant Physiol. Plant Mol. Biol. 48:575-608.

Heath, M. C. 1971. Haustorial sheath formation in cowpea leaves immune to rust infection. Phytopathology 61:383-388.

Jacobs, A. K., Lipka, V., Burton, R. A., Panstruga, R., Strizhov, N., Schulze-Lefert, P., and Fincher, G. B. 2003. An Arabidopsis callose synthase, GSL5, is required for wound and papillary callose formation. Plant Cell 15:2503-2513.

Jin, Y., Szabo, L. J., Pretorius, Z. A., Singh, R. P., Ward, R., and Fetch, T. 2008. Detection of virulence to resistance gene $\mathrm{Sr} 24$ within race TTKS of Puccinia graminis f. sp. tritici. Plant Dis. 92:923-926.

Kemen, E., Kemen, A. C., Rafiqi, M., Hempel, U., Mendgen, K., Hahn, M., and Voegele, R. T. 2005. Identification of a protein from rust fungi transferred from haustoria into infected plant cells. Mol. Plant-Microbe Interact. 18:1130-1139.

Knott, D. R. 1990. Near-isogenic lines of wheat carrying genes for stem rust resistance. Crop Sci. 30:901-905.

Koch, E., and Slusarenko, A. 1990. Arabidopsis is susceptible to infection by a downy mildew fungus. Plant Cell 2:437-445.

Leonard, K. J., and Szabo, L. J. 2005. Stem rust of small grains and grasses caused by Puccinia graminis. Mol. Plant Pathol. 6:99-111.

Manning, V. A., and Ciuffetti, L. M. 2005. Localization of Ptr ToxA produced by Pyrenophora tritici-repentis reveals protein import into mesophyll cells. Plant Cell 17:3203-3212.

McIntosh, R. A., Wellings, C. R., and Park, R. F. 1995. Wheat Rust-An Atlas of Resistance Genes. Kluwer Academic Publishers, London.

Melotto, M., Underwood, W., Koczan, J., Nomura, K., and He, S. Y. 2006. Plant stomata function in innate immunity against bacterial invasion. Cell 126:969-980.

Moerschbacher, B. M., Noll, U., Gorrichon, L., and Reisener, H. J. 1990. Specific inhibition of lignification breaks hypersensitive resistance of wheat to stem rust. Plant Physiol. 93:465-470.

Nicaise, V., Roux, M., and Zipfel, C. 2009. Recent advances in PAMPtriggered immunity against bacteria: Pattern recognition receptors watch over and raise the alarm. Plant Physiol. 150:1638-1647.

Nirmala, J., Drader, T., Lawrence, P. K., Yin, C., Hulbert, S. H., Steber, C. M., Steffenson, B. J., Szabo, L. J., von Wettstein, D., and Kleinhofs, A. 2011. Concerted action of two avirulent spore effectors activates reaction to Puccinia graminis 1 (Rpg1)-mediated cereal stem rust resistance. Proc. Natl. Acad. Sci. USA 108:14676-14681.

Nishimura, M. T., Stein, M., Hou, B. T., Vogel, J. P., Edwards, H., and Somerville, S. C. 2003. Loss of a callose synthase results in salicylic aciddependent disease resistance. Science 301:969-972.

Njau, P. N., Jin, Y., Huerta-Espino, J., Keller, B., and Singh, R. P. 2010. Identification and evaluation of sources of resistance to stem rust race $\mathrm{Ug} 99$ in wheat. Plant Dis. 94:413-419. 
Pretorius, Z. A., Singh, R. P., Wagoire, W. W., and Payne, T. S. 2000. Detection of virulence to wheat stem rust resistance gene Sr31 in Puccinia graminis. f. sp. tritici in Uganda. Plant Dis. 84:203.

Rafiqi, M., Ellis, J. G., Ludowici, V. A., Hardham, A. R., and Dodds, P. N. 2012. Challenges and progress towards understanding the role of effectors in plant-fungal interactions. Curr. Opin. Plant Biol. 15:477-482.

Roelfs, A. P., Singh, R. P., and Saari, E. E. 1992. Rust Diseases of Wheat: Concepts and Methods of Disease Management. CIMMYT, D.F, Mexico.

Rohringer, R., and Heitefuss, R. 1984. Histological and molecular biology of host-parasite specificity. Pages 193-293 in: The Cereal Rusts. A. P. Roelfs and W. R. Bushnell, eds. Academic Press, Orlando, FL.

Rohringer, R., Kim, W. K., and Samborski, D. J. 1979. A histological study of interactions between avirulent races of stem rust and wheat containing resistance genes $\operatorname{Sr} 5$, Sr6, Sr8 or Sr22. Can. J. Bot. 57:324-331.

Rowell, J. B. 1981. Relation of postpenetration events in Idaed 59 wheat seedlings to low receptivity to infection by Puccinia graminis f. sp. tritici. Phytopathology 71:732-736.

Singh, R. P., Hodson, D. P., Huerta-Espino, J., Jin, Y., Bhavani, S., Njau, P., Herrera-Foessel, S., Singh, P. K., Singh, S., and Govindan, V. 2011. The emergence of $\mathrm{Ug} 99$ races of the stem rust fungus is a threat to world wheat production. Annu. Rev. Phytopathol. 49:465-481.

Sivaguru, M., Fujiwara, T., Samaj, J., Baluska, F., Yang, Z., Osawa, H., Maeda, T., Mori, T., Volkmann, D., and Matsumoto, H. 2000. Aluminum-induced
1->3-beta-D-glucan inhibits cell-to-cell trafficking of molecules through plasmodesmata. A new mechanism of aluminum toxicity in plants. Plant Physiol. 124:991-1006.

Stakman, E. C., Stewart, D. M., and Loegering, W. Q. 1962. Identification of physiologic races of Puccinia graminis var. tritici. Agriculture Research Service, U.S. Department of Agriculture. E617 (revised).

Thordal-Christensen, H., Gregersen, P. L., and Collinge, D. B. 2000. The barley/ Blumeria (syn. Erysiphe) graminis interaction. Pages 77-100 in: Mechanisms of Resistance to Plant Diseases. A. Slusarenko, R. Fraser, and L. C. van Loon, eds. Kluwer Academic Publishers, Dordrecht, The Netherlands.

Vance, C., and Sherwood, R. T. 1976. Cycloheximide treatments implicate papilla formation in resistance of reed canarygrass to fungi. Phytopathology 66:498-502.

Vandesompele, J., De Preter, K., Pattyn, F., Poppe, B., Van Roy, N., De Paepe, A., and Speleman, F. 2002. Accurate normalization of realtime quantitative RT-PCR data by geometric averaging of multiple internal control genes. Online publication. Genome Biol. 3:research0034research0034.11.

Wang, X., McCallum, B. D., Fetch, T., Bakkeren, G., Marais, G. F., and Saville, B. J. 2012. Comparative microscopic and molecular analysis of Thatcher near-isogenic lines with wheat leaf rust resistance genes $L r 2 a$, Lr3, $\operatorname{LrB}$ or $\operatorname{Lr} 9$ upon challenge with different Puccinia triticina races. Plant Pathol. 62:698-707. 